AAAJ

32,6

\section{8}

\title{
Poetry, prose, literature and insights
}

\section{Government research evaluations}

Universities were once founded, for the public good

It seems that this goal, is no longer understood

Government research evaluations, now rule the day

Having come to Australia, from the UK

They have moved beyond a periodic exercise

And have unconsciously transformed academic lives!

We've become professional players, of this evaluation game

With scholarship no longer valued the same

Colleagues and friends, in fierce competition

Sharing of ideas, are replaced with suspicion

Academic freedom is so fast disappearing

As it is the metrics that we all are fearing

Inquiry and teaching once ruled academic life

Now these evaluations are causing much strife

No points did we earn for our creative piece

As our metric count, it did not increase

We raise important issues, that is for sure

To think we'd get applauded, would be premature

SCImago, Quartiles, and Citation scores

We find ourselves facing new kinds of wars

Clarivate has now been added to the measure

There's no time at all for any type of leisure

Accounting scholars are certainly under the hammer

As for a small group of top journals we clamour

DVCs vigilantly monitor their publication bank

Because all that they care for is a good university rank

The funding model now to the metrics is tied

Those bringing in money are viewed with pride

Business school income helps ease funding strains

Yet accounting scholars see little of those gains

Deans, they play the game of name and shame

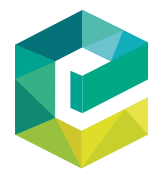

Accounting, Auditing \& Accountability Journal Vol. 32 No. 6, 2019 pp. $1858-1859$

(C) Emerald Publishing Limited 0951-3574

DOI 10.1108/AAAJ-12-2018-3775
With accounting scholars, so easy to frame

Do they care for the increasing student numbers these scholars teach

And that time for research is out of reach?

Anger and aggression of scholars are common threats

While physical and mental stress both cause regrets

You may be writing a book that will be widely read

If you think that counts, you are sadly misled

The fact that your research may help the nation

Can be lost in the government's research evaluation 
Publish or perish is never enough

Impact and engagement is our new handcuff!

What should we do in this world of metrics?

Perhaps to best go with the words of Maverick

Choose a path fuelled by your passion

Do honest work and trust your senses, not fashion

Write to make the world a better place

In this relentless metric craze!!
Poetry, prose, literature and insights

Ann Martin-Sardesai

School of Business and Law,

Central Queensland University, Brisbane, Australia, and

Lyn Daff

School of Commerce West Street, University of Southern Queensland, Queensland, Australia

\section{Further reading}

Guthrie, J., Parker, L., Dumay, J. and Milne, M. (2019), "What counts for quality in interdisciplinary accounting research in the next decade", Accounting, Auditing \& Accountability Journal, Vol. 32 No. 1, pp. 2-25.

Martin-Sardesai, A., Irvine, H., Tooley, S. and Guthrie, J. (2017a), "Government research evaluations and academic freedom: a UK and Australian comparison", Journal of Higher Education Research and Development, Vol. 36 No. 2, pp. 372-385.

Martin-Sardesai, A., Irvine, H., Tooley, S. and Guthrie, J. (2017b), "Organizational change in an Australian university: responses to a research assessment exercise", British Accounting Review, Vol. 49 No. 4, pp. 399-412. 